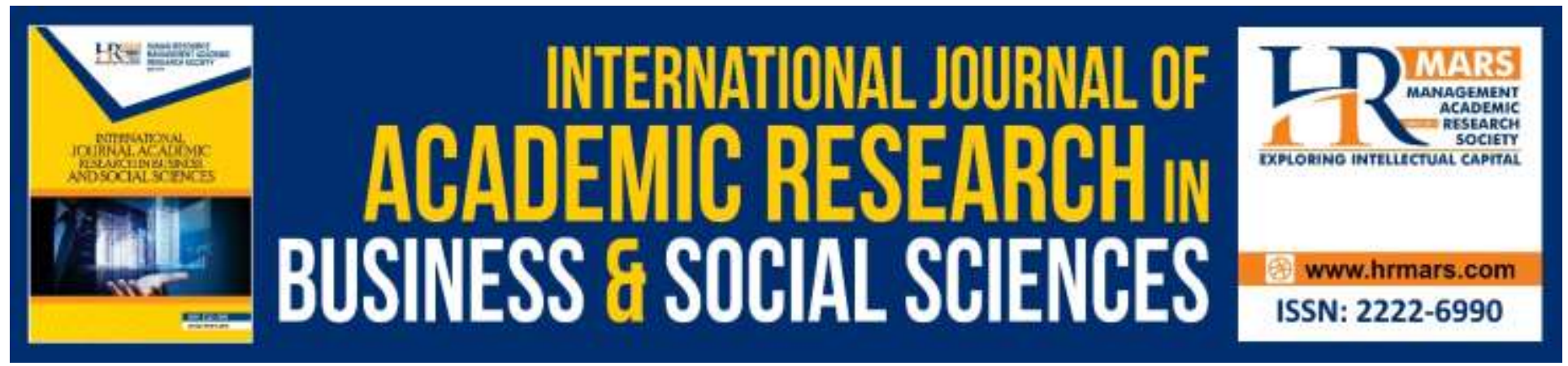

\title{
Causal Links between Trade Openness and Foreign Direct Investment in Malaysia
}

Syazwani Binti Mohd. Sazali, Mohd. Afandi Bin Abu Bakar, Aw Yang Huey, Mohd. Safwan Bin Ghazali

To Link this Article: http://dx.doi.org/10.6007/IJARBSS/v8-i1/4067

DOI:10.6007/IJARBSS/v8-i1/4067

Received: 26 Nov 2017, Revised: 11 Jan 2018, Accepted: 25 Jan 2018

Published Online: 29 Jan 2018

In-Text Citation: (Sazali, Bakar, Huey, \& Ghazali, 2018)

To Cite this Article: Sazali, S. B. M., Bakar, M. A. B. A., Huey, A. Y., \& Ghazali, M. S. Bin. (2018). Causal Links between Trade Openness and Foreign Direct Investment in Malaysia. International Journal of Academic Research in Business and Social Sciences, 8(1), 930-937.

Copyright: (C) 2018 The Author(s)

Published by Human Resource Management Academic Research Society (www.hrmars.com)

This article is published under the Creative Commons Attribution (CC BY 4.0) license. Anyone may reproduce, distribute, translate and create derivative works of this article (for both commercial and non-commercial purposes), subject to full attribution to the original publication and authors. The full terms of this license may be seen at: http://creativecommons.org/licences/by/4.0/legalcode

Vol. 8, No.1, January 2018, Pg. 930 - 937

Full Terms \& Conditions of access and use can be found at http://hrmars.com/index.php/pages/detail/publication-ethics 


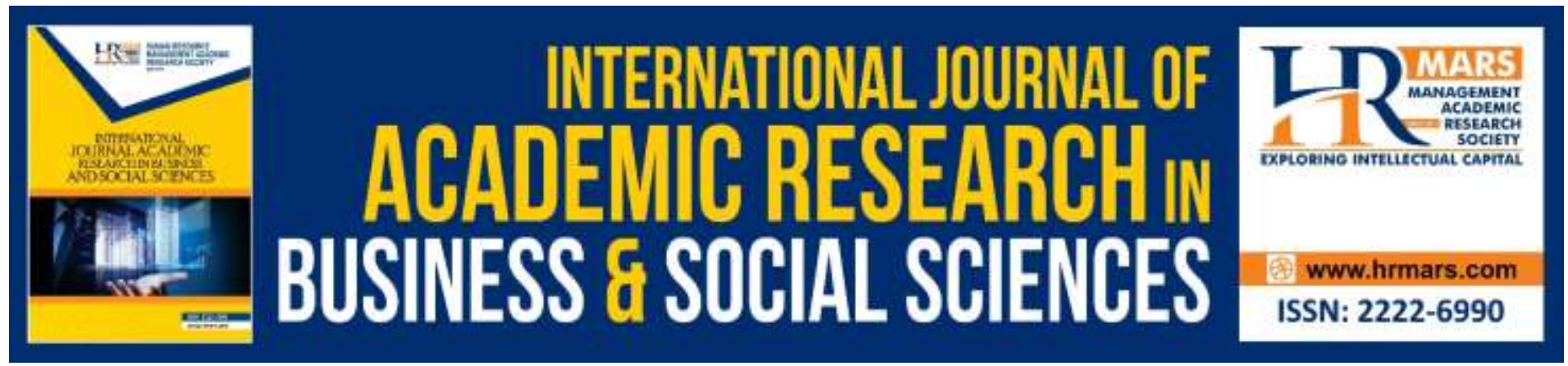

\title{
Causal Links between Trade Openness and Foreign Direct Investment in Malaysia
}

\author{
Syazwani Binti Mohd. Sazali \\ Group Leader, AEON Co. (M) Bhd., Bandar Dato' Onn, 81100 Johor Bahru, Malaysia.
}

\section{Mohd. Afandi Bin Abu Bakar}

Lecturer, Department of Economics, Faculty of Business and Management, Universiti Teknologi

MARA Seri Iskandar Campus, Seri Iskandar, 32610 Perak, Malaysia.

\section{Aw Yang Huey}

Lecturer, Department of Economics, Faculty of Business and Management, Universiti Teknologi MARA Seri Iskandar Campus, Seri Iskandar, 32610 Perak, Malaysia.

\section{Mohd. Safwan Bin Ghazali}

Lecturer, Department of Business, Faculty of Entrepreneurship and Business, University Malaysia Kelantan, 16100 Pengkalan Chepa, Kelantan.

\begin{abstract}
This study has examined the causal relationships between trade openness and foreign direct investment (FDI) in Malaysia using annual time series data. Throughout this study, the exchange rate and economic growth acted as the control variables. Data were collected from 1977 to 2015 and were analysed using the unit root test and the Granger causality test. The autoregressive model was employed to remove autocorrelation from rising in this model. The result of the Granger causality test indicated that there was a unidirectional causality between trade openness and FDI. It also showed that trade openness has a positive and significant impact on the FDI. All independent variables, namely, exchange rate, economic growth and trade openness, were significant in explaining FDI inflows in Malaysia. Therefore, this study has concluded that a good combination of these independent variables would attract more inflows of FDI into Malaysia. In addition, the Malaysian government has to implement policies that favour trade openness, such as reducing trade barriers, to encourage more FDI inflows into Malaysia to promote higher economic growth.
\end{abstract}

Keywords: Foreign Direct Investment, Trade Openness, Granger Causality Test. 


\section{Introduction}

Foreign direct investment (FDI) in Malaysia has registered a net inflow of RM43.4 billion in 2015 compared to RM35.3 billion in 2014. Of all the states in Malaysia, Penang attracted the highest amount of FDI in 2015. According to MIDF Research chief economist Dr Kamaruddin Mohd Nor, Malaysia will be able to attract high-quality FDI in the years to come since we have strong economics foundations, infrastructure, and Economic Transformation Programmes (Supriya, 2016). The income from FDI in 2015 was mainly generated from equity and investment fund shares (Department of Statistics, 2015). The top investing countries were Singapore, Japan, China and Hong Kong, Netherlands, and United States. The sectors of interest include manufacturing, mining and quarrying, construction, wholesale and retail, information and communication, and finance and shared services (MIDA, 2016).

UOB Bank economist, Julia Goh, described Malaysia's FDI as stable on a net basis, averaging RM9 billion per quarter since 2010 (Damodaran, 2017). In addition, FDIs that entered Malaysia had played an important role in the economic growth that led to a promising growth of 35 per cent per annum of compound annual growth rate, which was a cumulative of RM 253 billion since 2010 (Damodaran, 2017).

Data on the net inflow of FDI in Malaysia from 2000 to 2015 are as listed in Table 1:

Table 1: Malaysia's FDI net inflows

\begin{tabular}{|c|c|}
\hline Year & RM billion \\
\hline 2010 & 29.3 \\
\hline 2011 & 32.9 \\
\hline 2012 & 28.5 \\
\hline 2013 & 38.2 \\
\hline 2014 & 35.3 \\
\hline 2015 & 43.4 \\
\hline
\end{tabular}

Sources: Department of Statistics Malaysia and Malaysian Investment Development Authority.

As shown in Table 1, the value of FDI net inflows was quite stable from 2010 to 2015, which increased from RM28 billion to RM44 billion and a general uptrend can be seen over the years. Nevertheless the spillover effects of FDI in Malaysia need to be considered too. FDI may generate positive spillover through external effects, such as increasing the level of human capital in Malaysia, thus, increasing the productivity of local firms. However, Gorodnichenko et al. found that there was no support for the hypothesis that spillovers are greater for FDIs with more advanced technology. Their research has collected evidence from 17 emerging market economies (Gorodnichenko et al., 2014).

This current paper will examine the causal relationships between trade openness and FDI in Malaysia using the annual time series data from 1977 to 2015. Throughout this study, the exchange rate and economic growth will act as control variables.

\section{Literature Review}

Free trade has been the engine of economic growth. It can contribute to economic growth of a country based on comparative advantage, as explained by classical economist, Adam Smith and 
David Ricardo. Countries will specialize in the production of goods where they have the ability to produce at a lower opportunity cost. International specialization will increase world output. This means that the resources are being used efficiently and consumers can consume more goods than before. Thus, free trade should be encouraged to increase the world's standard of living.

Baharom et al. (2008) examined the role of trade openness and FDI in influencing the economic growth in Malaysia from 1975 to 2005. They used the Bounds testing approach and found that trade openness was positively associated to and statistically significant in determining the economic growth, both in the short-run and long-run. This testing approach will check the existence of a level relationship between a dependent variable and a set of regressors, when it is not known with certainty whether the underlying regressors are a trend or first difference stationary. The results from this test showed that FDI was significant in influencing economic growth, both in the short-run and long-run. They also found that FDI was positively associated with economic growth in the short-run, but negatively associated with economic growth in the long-run. In addition, they revealed that the control variable (the exchange rate) was also significant in influencing economic growth in the short-run and long-run.

A study by Kakar and Khilji (2011) investigated the growth rate in Pakistan and Malaysia. This study has shown that trade openness is a key determinant of economic growth. They discovered that trade openness could facilitate economic growth due to several factors, such as economics of scale, learning by doing, and increasing efficiency through competition. Findings from them using Johansen co-integration test and the error correction model, indicated that there was a long-run equilibrium in the model. The result showed that trade openness was positively associated and statistically significant in affecting the economic growth in Pakistan and Malaysia in the long-run. They gathered secondary data from 1980 to 2010, and from the ADF test, found that all the variables were integrated in the same order, i.e., order one I(1). The result from the Granger causality test showed that trade openness Granger cause economic growth in Pakistan. Meanwhile, FDI and exchange rate have no significant impact on the economic growth in Pakistan. As for Malaysia, the result indicated that all variables, except FDI, had significantly influenced the economic growth, and that unidirectional causality existed between trade openness, exchange rate and economic growth. The direction of causality went from trade to GDP and exchange rate to GDP. Nonetheless, there was a reverse causality between FDI and GDP growth in Malaysia.

Similarly, Yusoff and Nuh (2015) investigated the determinants of Thailand's economic growth using the Granger causality tests. They found that there was an establishing link between international trade and economic growth. The results also revealed that both FDI and international trade have positively and significantly contributed to the economic growth of Thailand in recent years. The researchers urged the policymakers in Thailand to liberalize its economy, such as by reducing government regulations and restrictions to encourage more free trade and FDI inflows towards achieving a higher economic development in Thailand.

Sharma and Kaur (2013) examined the causal relationships between FDI and international trade in India and China by using Granger causality tests. They used secondary data from 1976 to 
2011 and found out that there was unidirectional causality running from FDI to imports and FDI to exports. However, bidirectional causality existed between imports and exports in China. They discovered that the results were different for India, whereby bidirectional causality existed between FDI and imports; FDI and exports; and exports and imports.

\section{Research Objective}

This study used trade openness as the main variable to examine the causal relationships between trade openness and foreign direct investment in Malaysia. Throughout this study, the exchange rate and economic growth acted as the control variables, for investigating the relationships between exchange rate and economic growth towards FDI in Malaysia.

In order to understand these relationships, a set of alternative hypotheses were developed.

$\mathrm{H}_{1}$ : There is a positive relationship between trade openness and FDI.

$\mathrm{H}_{2}$ : Trade openness does Granger cause FDI inflow.

\section{Research Methodology}

This study applied the annual time series data, which were gathered from 1977 to 2015. The Augmented Dickey-Fuller (ADF) test was performed to test for stationary data and to determine the order of integration between the variables. The autoregressive model was employed to remove autocorrelation from this model. In addition, the Variance Inflation Factors (VIF) was used to help detect the problem of multicollinearity. The Granger-causality analysis was also conducted to assess the existence of any unidirectional or bidirectional relationships between trade openness and FDI in Malaysia. In order to determine the relationships between the dependent variable and the independent variables, multiple linear regressions were performed with logarithmic transformations.

\section{Results}

The results for the ADF test showed that all the variables were stationary after the first differences were employed. This means that all variables were integrated of order one I(1). Table 2 shows the results for a unit root test of all variables in this study, which comprised of foreign direct investment (FDI), exchange rate (EXC), economic growth (GDP) and trade openness (TR).

Table 2: Unit Root Test

\begin{tabular}{|l|l|l|}
\hline Variables & ADF at level & ADF at $1^{\text {st }}$. Difference \\
\hline $\operatorname{In}(\mathrm{FDI})$ & $<0.962786>;(0.9074)$ & $<-7.797372>;(0.0000)^{* * *}$ \\
\hline $\operatorname{In}(\mathrm{EXC})$ & $<0.254705>;(0.7543)$ & $<-6.296578>;(0.0000)^{* * *}$ \\
\hline $\operatorname{In}(\mathrm{GDP})$ & $<-0.487302>;(0.4946)$ & $<-9.912426>;(0.0000)^{* * *}$ \\
\hline $\operatorname{In}(\mathrm{TR})$ & $<0.568223>;(0.8341)$ & $<-3.933855>;(0.0003)^{* * *}$ \\
\hline
\end{tabular}

Note: t-statistics in <> and $\mathrm{p}$-value in (). All the $* * *$ denotes the rejection of the null hypothesis of non-stationary at $1 \%$ significance level.

The autoregressive model was employed to remove autocorrelation from rising in this model. The following equation is the estimation equation after the first difference was applied in the unit root test and the time series variables have been transformed to natural logarithm: 


$$
\mathrm{D} \ln (\mathrm{FDI})={ }_{\beta 0}+{ }_{\beta 1} \mathrm{D} \ln (\mathrm{EXC})+{ }_{\beta 2} \mathrm{D} \ln (\mathrm{GDP})+{ }_{\beta 3} \mathrm{D} \ln (\mathrm{TR})+\mathrm{FDI}(-1)+\mu_{\mathrm{i}}
$$

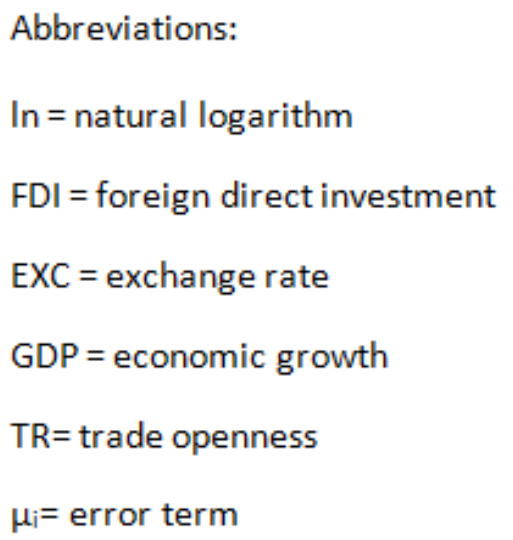

The Variance Inflation Factor (VIF) was used to detect the problem of multicollinearity. Table 3 shows the result of the multicollinearity test. The VIF values for the independent variables were smaller than 5, which indicated that no severe multicollinearity problem existed in the regression.

Table 3: Multicollinearity test

\begin{tabular}{|l|c|c|}
\hline Independent variables & VIF & Multicollinearity problem \\
\hline$D \ln (\mathrm{EXC})$ & 1.161620 & $<5$ (no multicollinearity exist) \\
\hline $\mathrm{D} \ln (\mathrm{GDP})$ & 1.118504 & $<5$ (no multicollinearity exist) \\
\hline $\mathrm{D} \ln (\mathrm{TR})$ & 1.422278 & $<5$ (no multicollinearity exist) \\
\hline FDI(-1) & 2.602598 & $<5$ (no multicollinearity exist) \\
\hline
\end{tabular}

Table 4 shows the result of the Granger causality test.

Table 4: Granger causality test

\begin{tabular}{|c|c|c|}
\hline Null Hypothesis & F-statistics & Probability \\
\hline$D \ln ($ TR) does not Granger cause $D \ln ($ FDI $)$ & 4.47553 & $0.0425^{* *}$ \\
\hline$D \ln ($ FDI) does not Granger cause DIn(TR) & 0.61021 & 0.4406 \\
\hline
\end{tabular}

Note: ${ }^{* *}$ indicates the rejection of the null hypothesis at $5 \%$ significance level.

The result of the Granger causality test indicated that Malaysia has unidirectional relationship between trade openness and FDI. It also showed that the direction of causality ran from trade openness to FDI. This means that trade openness does Granger cause inflow of FDI in Malaysia. Table 5 shows the multiple regression analysis. 
INTERNATIONAL JOURNAL OF ACADEMIC RESEARCH IN BUSINESS AND SOCIAL SCIENCES Vol. 8, No.1, January 2018, E-ISSN: 2222-6990 @ 2018 HRMARS

Table 5: Model Summary

\begin{tabular}{|l|l|l|l|l|}
\hline \multicolumn{1}{|c|}{ Variable } & \multicolumn{1}{c|}{ Coefficient } & \multicolumn{1}{c|}{ Std. Error } & \multicolumn{1}{c|}{ t-statistic } & \multicolumn{1}{c|}{ Prob. } \\
\hline C & 0.427585 & 0.194517 & 2.198191 & 0.0383 \\
\hline DIn(EXC) & 0.232672 & 0.130909 & 1.777350 & 0.0469 \\
\hline$D \ln ($ GDP) & 0.252360 & 0.141984 & 1.777380 & 0.0284 \\
\hline$D \ln (T R)$ & 0.442989 & 0.234409 & 1.892398 & 0.0491 \\
\hline FDI(-1) & $3.20 E-05$ & $1.30 E-05$ & 2.459621 & 0.0219 \\
\hline
\end{tabular}

Regression model:

$\ln ($ FDI $)=0.427585+\ln 0.232672 \mathrm{EXC}+\ln 0.252360 \mathrm{GDP}+\ln 0.442989 \mathrm{TR}-\mathbf{0 . 0 0 0 0 3 . 2}$ FDI(-1) $\mathrm{R}^{2}=0.580924$

The regression result indicated that $58.09 \%$ of the dependent variable in the model can be explained by the independent variables $\left(R^{2}=0.580924\right)$. The regression line indicated that there was a significant and positive relationship between the independent variables and the dependent variable.

\section{Conclusion}

The results in this study have shown that trade openness, which was the main variable, had a short-run unidirectional relationship with FDI inflows in Malaysia. This finding is consistent with the study conducted by Kakar and Khilji (2011) who investigated the growth rate in Pakistan and Malaysia. The empirical results from their study have shown that trade openness was a key determinant of the economic growth in both countries. All three independent variables in this model, namely, exchange rate, economic growth, and trade openness, have positive relationships with FDI. Furthermore, the analysis showed that all independent variables were significant in explaining FDI inflows in Malaysia. Therefore, this study has concluded that a good combination of these independent variables will attract more inflows of FDI into Malaysia. In addition, the Malaysian government has to implement policies that favour trade openness, such as reducing trade barriers to encourage more FDI inflows into Malaysia to promote a higher economic growth. This study had only included three independent variables. In order to have a more conclusive answer, future researches should include more independent variables, such as market size, inflation rate, wage rate, and human capital.

\section{Acknowledgement}

We would like to thank Ms. Ho of Department of Statistics, Malaysia for her assistance with the collection of our data.

\section{Corresponding Author}

Mohd. Afandi Bin Abu Bakar, Senior Lecturer, Department of Economics, Faculty of Business and Management, Universiti Teknologi MARA Seri Iskandar Campus, Malaysia.

Email: mohda254@perak.uitm.edu.my 
INTERNATIONAL JOURNAL OF ACADEMIC RESEARCH IN BUSINESS AND SOCIAL SCIENCES

Vol. 8, No.1, January 2018, E-ISSN: 2222-6990 @ 2018 HRMARS

\section{References}

Baharom, A. H., Habibullah, M. S., \& Royfaizal, R. C. (2008). The relationship between trade openness, foreign direct investment and growth: case of Malaysia. MPRA paper no. 11928.

Blomström, M., \& Kokko, A. (2002). FDI and Human Capital: A Research Agenda. OECD Development Centre Working Papers 195, OECD Publishing.

Damodaran, R. (2017), Malaysia has strong FDI prospects, says economist, New Straits Times, Kuala Lumpur.

Department of Statistics Malaysia. (2015). Retrieved from http://www.dosm.gov.my/

Granger C. W. J. (1988). Some recent development in a concept of causality. Journal of Econometrics, 39(1-2), 199-211.

Gorodnichenko, Y., Svejnar, J., \& Terrell, K. (2014). When Does FDI Have Positive Spillovers? Evidence from 17 Transition Market Economies. Journal of Comparative Economics, 42(4), 954-969.

Gujarati, D. N., \& Porter, D. C. (2010). Essentials of Econometrics. New York: McGraw Hill International Edition.

Kakar, Z. K., \& Khilji, B. A. (2011). Impact of FDI and trade openness on economic growth: a comparative study of Pakistan and Malaysia. Theoretical and Applied Economics, 18(11), 53-58.

MIDA. (2016). Malaysia Investment Development Authority. Retrieved from: http://www.mida.gov.my/

Pesaran, M. H., Shin, Y., \& Smith, R. J. (2010). Bounds Testing Approaches to the analysis of level relationships. Journal of Applied Econometrics, 16(3), 289-326.

Sekaran, U., \& Bougie, R. (2013). Research Methods for Business: A skill building approaches. UK: John Wiley \& Sons Ltd.

Sharma, R., \& Kaur, M. (2013). Causal Links between Foreign Direct Investments and Trade: A Comparative. Study of India and China. Eurasian Journal of Business and Economics, 6(11), 75-91.

Supriya, S. (2016), Malaysia's 2016 FDI inflow seen 'stable', The Edge Financial Daily, Kuala Lumpur.

Yusoff, M., \& Nuh, R. (2015). Foreign Direct Investment, Trade Openness and Economic Growth. Empirical Evidence from Thailand. Foreign Trade Review, 50(2), 73-84. 